\title{
Modern Practice-Oriented, Scientifically-Based Approaches of the Development of the Wrestling
}

\author{
V. A. Maksimovich ${ }^{1}$, A. I. Navojchik ${ }^{2}$, E. V. Znatnova ${ }^{3}$ and I. V. Tonkoblatova ${ }^{1}$ \\ 1. Department of Physical Education and Sport, Grodno State University named after Y. Kupala, Grodno 230023, Belarus \\ 2. Faculty of Physical Education, Grodno State University named after Y. Kupala, Grodno 230023, Belarus \\ 3. Department of Theory and Methodology of Physical Education, Grodno State University named after Y. Kupala, Grodno 230023, \\ Belarus
}

\begin{abstract}
The article describes the exemplary organization of the 2017 World Championships in Paris in Greco-Roman, freestyle and women's wrestling. The results of the world championships of 2011, 2015 and 2017 among the continents were analyzed and summed up. The development potential of the leading wrestling countries of the world is revealed. The specific proposals of the international federation (UWW and the "United World of Struggle") have been made.
\end{abstract}

Key words: World championship, wrestling, wrestling federation.

\section{Introduction}

The international federations in all sports, having carefully analyzed the results of the past Olympic cycle, are seeking new scientifically grounded opportunities to improve the popularization of the sport they lead [1]. A particular concern in this direction is the federation (UWW United Struggle World). Realizing that without strategic, comprehensively studied, in practice, scientifically-verified approaches, it is inconceivable to compete in the rapidly developing global sports.

\section{Discussion}

The first in the new Olympic cycle, the World Championships in Greco-Roman, freestyle and women's wrestling was held in Paris (France) from 21 to 26 August 2017. It is a surprising fact that Paris, the city where the Greco-Roman wrestling revived (then was called French), never took the World Cup. But at the beginning of the last century, the most prestigious, popular professional tournaments took place, one of which was won by the legendary Russian hero Ivan Poddubny [2].

Corresponding author: V. A. Maksimovich
During the championship, a federation congress was held, at which regular additions to the competition rules were adopted.

From 2018, the championships of the continents, the world will be held in 10 weight categories, and the Olympic Games in 6 weight categories (Table 1).

The three styles of wrestling (Greco-Roman, freestyle and women's) will be played 120 medals (40 in each form of struggle). In the Olympic program, there are 24 awards in each style (total of 72 medals). Table 1 shows the new weight categories for which all official competitions will be held.

Competitions will be held in two days. Weighing contestants will be held in the morning every day. Two hours after weighing, the competition starts. On the second day of the competition allowed admission plus two kilograms. From 2019, the second day of the competition will be weighed clean. For the passive conduct of the struggle the athlete will be put on the ground. The first four athletes will be scattered at the World Championships and the 2020 Olympics in Tokyo, Japan, according to the federation-rated rating of the previous year. These additions to the rules of the 
Journal of Sports Science 7 (2019) 16-23

doi: $10.17265 / 2332-7839 / 2019.01 .003$

Table 1 Weight categories of official international competitions and Olympic Games in Greco-Roman, freestyle and women's wrestling.

\begin{tabular}{|c|c|c|c|c|c|c|}
\hline \multirow{3}{*}{ № } & \multicolumn{6}{|c|}{ Wrestling styles } \\
\hline & \multicolumn{2}{|c|}{ Greco-Roman } & \multicolumn{2}{|c|}{ Freestyle } & \multicolumn{2}{|c|}{ Women's wrestling } \\
\hline & $\begin{array}{l}\text { Official competition } \\
\text { program }\end{array}$ & Olympic program & $\begin{array}{l}\text { Official competition } \\
\text { program }\end{array}$ & Olympic program & $\begin{array}{l}\text { Official competition } \\
\text { program }\end{array}$ & Olympic program \\
\hline 1. & till $55 \mathrm{~kg}$ & - & till $57 \mathrm{~kg}$. & till $57 \mathrm{~kg}$ & till $50 \mathrm{~kg}$. & till $50 \mathrm{~kg}$ \\
\hline 2. & $-/ /-60-/ /-$ & till $60 \mathrm{~kg}$. & $-/ /-61-/ /-$ & - & $-/ /-53-/ /-$ & $-/ /-53-/ /-$ \\
\hline 3. & $-/ /-63-/ /-$ & - & $-/ /-65-/ /-$ & $-/ /-65-/ /-$ & $-/ /-55-/ /-$ & - \\
\hline 4. & $-/ /-67-/ /-$ & $-/ /-67-/ /-$ & $-/ /-70-/ /-$ & - & $-/ /-57-/ /-$ & $-/ /-57-/ /-$ \\
\hline 5. & $-/ /-72-/ /-$ & - & $-/ /-74-/ /-$ & $-/ /-74-/ /-$ & $-/ /-59-/ /-$ & - \\
\hline 6. & $-/ /-77-/ /-$ & $-/ /-77-/ /-$ & $-/ /-79-/ /-$ & - & $-/ /-62-/ /-$ & $-/ /-62-/ /-$ \\
\hline 7. & $-/ /-82-/ /-$ & - & $-/ /-86-/ /-$ & $-/ /-86-/ /-$ & $-/ /-65-/ /-$ & - \\
\hline 8. & $-/ /-87-/ /-$ & $-/ /-87-/ /-$ & $-/ /-92-/ /-$ & - & $-/ /-68-/ /-$ & $-/ /-68-/ /-$ \\
\hline 9. & $-/ /-97-/ /-$ & $-/ /-97-/ /-$ & $-/ /-97-/ /-$ & $-/ /-97-/ /-$ & $-/ /-72-/ /-$ & - \\
\hline 10. & $-/ /-130-/ /-$ & $-/ /-130-/ /-$ & $-/ /-125-/ /-$ & $-/ /-125-/ /-$ & $-/ /-76-/ /-$ & $-/ /-76-/ /-$ \\
\hline
\end{tabular}

Table 2 Distribution of the first ten command places at the 2017 World Championships in Paris by freestyle, Greco-Roman and women's wrestling (by the first ten in each weight category).

\begin{tabular}{llllllllll}
\hline \multirow{2}{*}{ Place } & \multicolumn{3}{c}{ Freestyle } & \multicolumn{3}{c}{ Women wrestling } & \multicolumn{3}{c}{ Greco-Roman } \\
\cline { 2 - 9 } & Continent & Country & Points & Continent & Country & Points & Continent & Country & Points \\
\hline 1. & America & USA & 54 & Asia & Japan & 60 & Europe & Russia & 46 \\
2. & Europe & Russia & 53 & Europe & Belarus & 38 & Asia & Iran & 36 \\
3. & Europe & Georgia & 40 & America & USA & 38 & Europe & Turkey & 34 \\
4. & Europe & Turkey & 39 & Asia & Mongolia & 25 & Europe & Georgia & 30 \\
5. & Europe & Azerbaijan & 32 & America & Canada & 24 & Europe & Germany & 29 \\
6. & Asia & Japan & 28 & Europe & Turkey & 24 & Asia & Armenia & 28 \\
7. & America & Cuba & 23 & Asia & China & 20 & Europe & Hungary & 28 \\
8. & Asia & Kazakhstan & 18 & Europe & Romania & 18 & Asia & Kazakhstan & 24 \\
9. & Asia & Iran & 16 & Europe & Sweden & 18 & Europe & Azerbaijan & 22 \\
10. & Europe & Armenia & 16 & Africa & Nigeria & 17 & Asia & Korea & 21 \\
\hline
\end{tabular}

For the 1 st place 10 points are awarded, for the 2 nd -9 , for the 3 rd $-8 ; 5,6,7$-th $-4 ; 8$ th $-3 ; 9$ th -2 and for 10 th place -1 point.

competition are designed to develop the image, popularization, visibility, entertainment and understanding of the audience, fans of the outcome of wrestling matches.

The World Championship in wrestling held in Paris among specialists and admirers of wrestling art remained in the memory of an exemplary organized, entertaining, suitable for participants and spectators of the competition.

The competition was attended by 686 athletes representing 73 countries from five continents. In the Greco-Roman wrestling took part with 260 participants from 55 countries, in the free 237 athletes from 46 countries and in the women's wrestling there were 191 participants from 44 countries.

\section{Materials and Methods}

The results of the performance of national teams representing all continents of the planet in three styles of wrestling (freestyle, Greco-Roman and female) for the ten best results in eight weight categories are shown in Table 2.

In the freestyle wrestling, five teams (Russia, Georgia, Turkey, Azerbaijan, Armenia), representing Europe, made up 50\%, three countries (Japan, Kazakhstan, Iran) from Asia-30\% and two (USA , Cuba), from the Americas-20\% (Fig. 1).

In the women's wrestling (Fig. 2) in the number of countries in the top ten, there is a slight advantage of European athletes. Four countries (Belarus, Turkey, 
Romania, Sweden) won 98 points (40\%), at the same time, three countries representative of the Asian continent (Japan, Mongolia, China) 30\%, in terms of quality and quantity of medals won, significantly surpassed all continents. Two countries (USA, Canada) of the Americas scored 64 points $(20 \%)$ and ranked third. One country in Africa (Nigeria), scoring 21 points $(10 \%)$, closed the top ten. This is the only country in the African continent of the three types of wrestling that is among the ten leading wrestling countries in the world.
The most significant advantage of European wrestlers is observed in the Greco-Romans (fig.3). Seven countries (Russia, Turkey, Georgia, Germany, Armenia, Hungary, Azerbaijan) were among the top ten, accounting for 70\%, and only three countries (Iran, Kazakhstan and the Republic of Korea) representing Asia were in the top ten and respectively, eighth and tenth places $(30 \%)$.

The perceptible superiority of the European "classics" is also evident in the calculation of the medals being played for the championships (fig.4). Having won 22
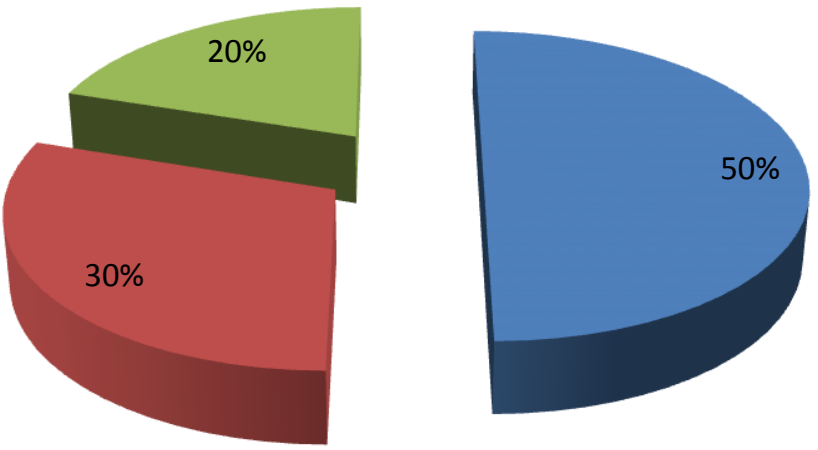

Europe (5 countries)

Asia (3 countries)

America ( 2 countries)

Fig. 1 The ratio of the number of countries representing the continents that are among the ten best teams in the world in freestyle wrestling at the 2017 World Championships in Paris.

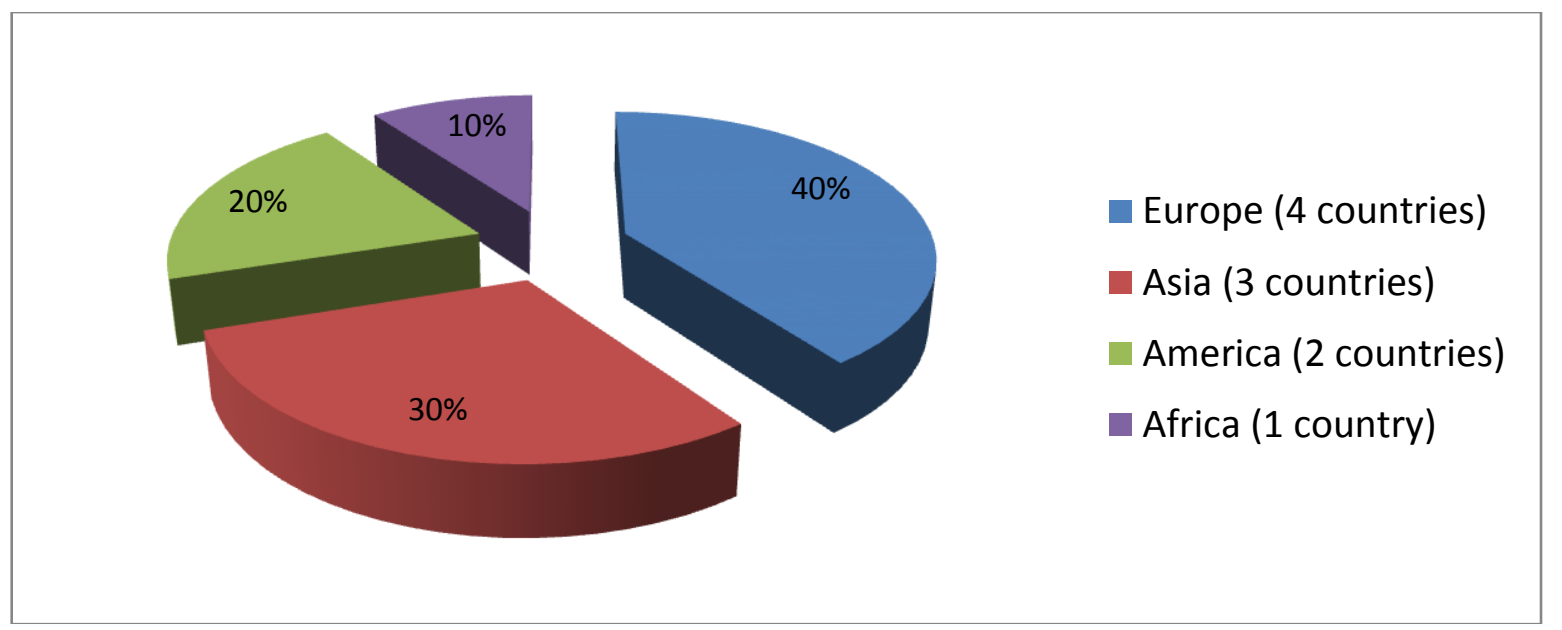

Fig. 2 Ratio of the number of countries representing the continents, which are among the ten best teams in the world in women's wrestling at the 2017 World Championships in Paris. 


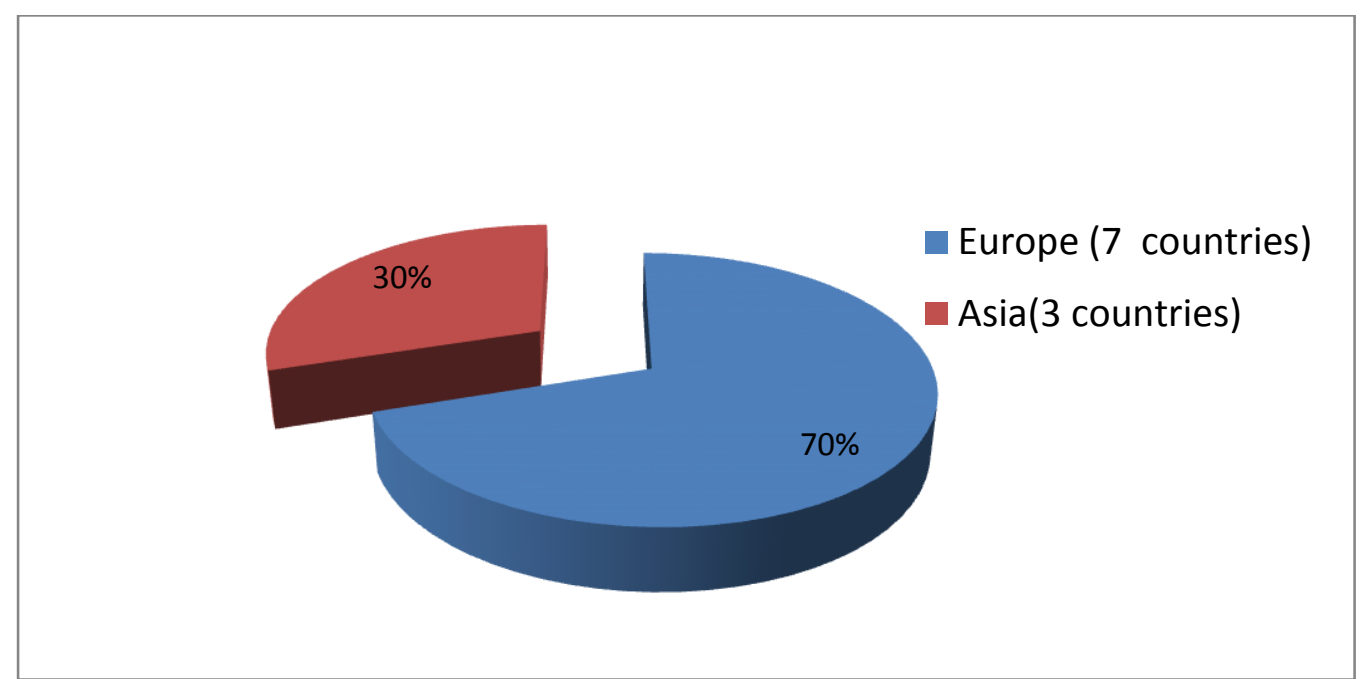

Fig. 3 The ratio of the number of countries representing the continents, which are among the ten best teams of the world in Greco-Roman wrestling at the 2017 World Championships in Paris.

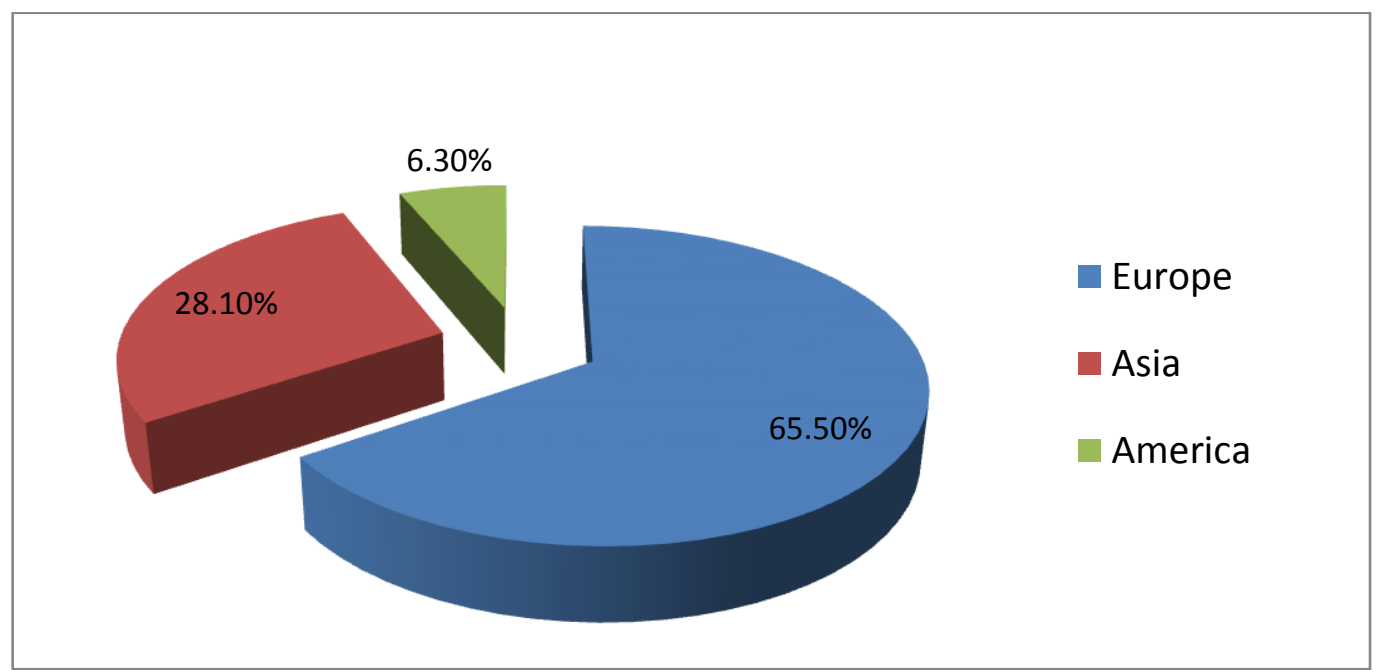

Fig. 4 Distribution of places among the continents by the number of medals at the 2017 World Championships in Paris in Greco-Roman wrestling.

medals $(65.6 \%)$ out of 32 played out on 6 gold and silver $(75 \%)$ and 10 bronze $(62.5 \%)$ is a vivid reflection of the above and is reflected in Table 3.

Asian athletes, winning 8 medals (28.1\%) systematically in all world championships and Olympic Games [3, 4] occupy the second line. They hold particular leading competition in small weight categories. Only two representatives $(6.3 \%)$ of the American continent, Oscar Pino (Cuba) and Yasmani Acosta (USA), were awarded bronze medals. The results of the World Cup 2017 in Paris once again confirm the need for urgent resuscitation of wrestling in all five continents.
The sensational event of the Paris Championship was that for the first time in the history of independence, the leading wrestling power did not win a single gold medal in the three styles of wrestling, but nevertheless, winning a total of ten medals (Greco-Roman - 4 medals, freestyle - 5, women's - 1 medal), won the first team place. The women's Russian team with one medal did not even hit the top ten teams in the world.

In Greco-Roman wrestling (Table 4), wrestlers from 17 countries were awarded medals, and participants from 34 countries were in the top ten of all weight categories. 
Table 3 Distribution of medals among continents at the 2017 World Greco-Roman Wrestling Championships in Paris (France).

\begin{tabular}{llllll}
\hline \multirow{2}{*}{ No. } & Continent & Gold & Silver & Bronze & Total medals \\
\cline { 3 - 6 } & Europe & $6(75 \%)$ & $6(75 \%)$ & $10(62,5 \%)$ & $22(65.6 \%)$ \\
1. & Asia & $2(25 \%)$ & $2(25 \%)$ & $4(50 \%)$ & $8(28.1 \%)$ \\
3. & America & 0 & 0 & $2(6.25 \%)$ & $2(6.3 \%)$ \\
4. & Africa & 0 & 0 & 0 & 0 \\
5. & Oceania & 0 & 0 & 0 & 0 \\
\hline Total & & 8 & 8 & 16 & 32 \\
\hline
\end{tabular}

Table 4 Champions and prize-winners of the World Championships in Greco-Roman Wrestling 2017 in Paris (France).

\begin{tabular}{|c|c|c|c|c|c|c|}
\hline $\begin{array}{l}\text { Weight } \\
\text { category }\end{array}$ & Continent & Gold & Continent & Silver & Continent & Bronze \\
\hline Till $59 \mathrm{~kg}$ & Asia & $\begin{array}{l}\text { Kanjiteru of Fumito } \\
\text { (Japan) }\end{array}$ & Asia & $\begin{array}{l}\text { Meirambek of } \\
\text { Ainagulov } \\
\text { (Kazakhstan) }\end{array}$ & $\begin{array}{l}\text { Europe } \\
\text { Asia }\end{array}$ & $\begin{array}{l}\text { Stepan Maranan (Russia) } \\
\text { Kim Sung-Guk (Republic of } \\
\text { Korea) }\end{array}$ \\
\hline Till $66 \mathrm{~kg}$ & Asia & $\begin{array}{l}\text { Ryu Han-Soo (Republic } \\
\text { Of Korea) }\end{array}$ & Europe & $\begin{array}{l}\text { Mateusz Bernatek } \\
\text { (Poland) }\end{array}$ & $\begin{array}{l}\text { Europe } \\
\text { Europe }\end{array}$ & $\begin{array}{l}\text { Artem Surkov(Russia) } \\
\text { Atakan Yuksel (Turkey) }\end{array}$ \\
\hline Till $71 \mathrm{~kg}$ & Europe & $\begin{array}{l}\text { Frank Shtabler } \\
\text { (Germany) }\end{array}$ & Asia & $\begin{array}{l}\text { Demeu Zhadraev } \\
\text { (Kazakhstan) }\end{array}$ & $\begin{array}{l}\text { Asia } \\
\text { Europe }\end{array}$ & $\begin{array}{l}\text { Muhammadali, Geranium } \\
\text { (Iran) } \\
\text { Kobashi Balint (Hungary) }\end{array}$ \\
\hline Till 75 kg & Europe & Victor Nemes (Serbia) & Europe & $\begin{array}{l}\text { Alexander Chirkin } \\
\text { (Russia) }\end{array}$ & $\begin{array}{l}\text { Europe } \\
\text { Asia }\end{array}$ & $\begin{array}{l}\text { Tamas Lorenz (Hungary) } \\
\text { Said Abdali (Iran) }\end{array}$ \\
\hline Till $80 \mathrm{~kg}$ & Europe & $\begin{array}{l}\text { Maxim Manukyan } \\
\text { (Armenia) }\end{array}$ & Europe & Radik Kuliev (Belarus) & $\begin{array}{l}\text { Europe } \\
\text { Europe }\end{array}$ & $\begin{array}{l}\text { Pascal Eisele (Germany) } \\
\text { Elvin Mursaliyev } \\
\text { (Azerbaijan) }\end{array}$ \\
\hline Till $85 \mathrm{~kg}$ & Europe & Metehan Bashar (Turkey) & Europe & Denis Kudla (Germany) & $\begin{array}{l}\text { Asia } \\
\text { Europe }\end{array}$ & $\begin{array}{l}\text { Hossein Nouri } \\
\text { (Iran) } \\
\text { Robert Kobiashvili } \\
\text { (Georgia) }\end{array}$ \\
\hline Till 98 kg. & Europe & $\begin{array}{l}\text { Arthur Aleksanyan } \\
\text { (Armenia) }\end{array}$ & Europe & Musa Evloev (Russia) & $\begin{array}{l}\text { Europe } \\
\text { Europe }\end{array}$ & $\begin{array}{l}\text { Revaz Kobiashvili (Georgia) } \\
\text { Bela Kiss (Hungary) }\end{array}$ \\
\hline Till $130 \mathrm{~kg}$ & Europe & Ryza Kayalp (Turkey) & Europe & Heiki Nabi (Estonia) & $\begin{array}{l}\text { America } \\
\text { America }\end{array}$ & $\begin{array}{l}\text { Oscar Pino (Cuba) } \\
\text { Yasmani Acosta (Chile) }\end{array}$ \\
\hline
\end{tabular}

Preserving the traditions of the Soviet school of wrestling, the Russian Greco-Romans and at the Paris World Cup, winning 4 medals (46 points) won a team victory.

The Russian Wrestling Federation together with the Sports Committee of Russia, the Board of Trustees, the Research Institute are developing and introducing new projects-"Wrestling and Wining", "Wrestling at School", which bring new impetus to attracting youth contingent in wrestling sections [2].

The leading sport in Iran is wrestling. Having won three (bronze) medals, the Iranian team scored 36 points and confidently took second place in the world rankings. By investing solid financial flows, using fanaticism and patriotism of their fellow citizens, the Iranian Wrestling Federation trains world-class athletes who successfully defend the country's sporting honor in planetary competitions

The Turkish team, having won two gold medals and one bronze, two points behind the Iranians, with 34 points, placed in third place. The undisputed leader of the team is the repeated champion of Europe, the world, the Olympic medalist in the most prestigious (heavy) weight category Reese Kayalp, replacing outstanding heavyweights Alexander Karelin (Russia) and Mihein Lopez (Cuba). The fusion of the Turkish team is made 
up not only of wrestlers and coaches, but also of highly qualified, judges, which is quite significant in wrestling.

Naturally gifted, with a rich technical arsenal, the team of Georgia is staffed. Having won two bronze awards and scored 30 points, she took the fourth team place.

With German punctuality, German wrestlers, caressed by the increased attention of their fans, improve their athletic performance from start to start. In the Paris championship, they won three medals (gold, silver and bronze). Having gained 29 points, they took the fifth place, and the wrestler in the weight category up to $71 \mathrm{~kg}$. Frank Stambler is recognized as the best wrestler of the championship.

Armenia, with two champions Maxim Manukyan $(80 \mathrm{~kg})$ and Arthur Aleksanyan, scored 28 points and shared 6-7 place with the Hungarian team.

Both countries have sufficiently equipped with modern simulators, medical and recovery equipment, scientific and methodological laboratories of the Olympic training center.

In Armenia, this is the sports base "Tsakhkadzor", located at an altitude of 850 meters above sea level, the legacy of the Soviet Union is currently being transferred to private entrepreneurship and is successfully developing.

In Hungary, there are several modern Olympic integrated bases where athletes, especially wrestlers from all over the world, come for joint training camps (Table 5).

Comparing the results of the two pre-Olympic licensed world championships 2011, 2015 and the first in the Olympic cycle championship 2017 in Paris, it is obvious that the primacy of European wrestlers is indisputable (Table 6).Of the 92 medals played at three championships, 62 medals of various denominations are taken away by representatives of the old world. Asia, having won 23 medals (25\%) of various denominations, was firmly established in second place. The Pan-American continent won 2 medals each $(7 \%)$ in the championships of Istanbul and Paris, and in Las Vegas 3 medals (9.4\%) ranked third. Africa and Oceania systematically remain without awards from world championships and the Olympic Games [5-7].

Table 5 Distribution of medals among the countries included in the top ten at the 2017 World Championships in Greco-Roman Wrestling in Paris (France).

\begin{tabular}{|c|c|c|c|c|c|c|}
\hline \multirow{2}{*}{ No. } & \multirow{2}{*}{ Country } & \multicolumn{3}{|c|}{ Medals } & \multirow{2}{*}{ - Total medals } & \multirow{2}{*}{ Points } \\
\hline & & Gold & Silver & Bronze & & \\
\hline 1. & Russia & 0 & 2 & 2 & 4 & 46 \\
\hline 2. & Iran & 0 & 0 & 3 & 3 & 36 \\
\hline 3. & Turkey & 2 & 0 & 1 & 3 & 34 \\
\hline 4. & Georgia & 0 & 0 & 2 & 2 & 30 \\
\hline 5. & Germany & 1 & 1 & 1 & 3 & 29 \\
\hline 6. & Armenia & 2 & 0 & 0 & 2 & 28 \\
\hline 7. & Hungary & 0 & 0 & 3 & 3 & 28 \\
\hline 8. & Kazakhstan & 0 & 2 & 0 & 2 & 24 \\
\hline 9. & Azerbaijan & 0 & 0 & 1 & 1 & 22 \\
\hline 10. & Korea & 1 & 0 & 1 & 2 & 21 \\
\hline 11. & Serbia & 1 & - & - & 1 & \\
\hline 12. & Japan & 1 & - & - & 1 & \\
\hline 13. & Belarus & - & 1 & - & 1 & \\
\hline 14. & Poland & - & 1 & - & 1 & \\
\hline 15. & Estonia & - & 1 & - & 1 & \\
\hline 16. & Kuba & - & - & 1 & 1 & \\
\hline 17. & Chile & - & - & 1 & 1 & \\
\hline Total & & 8 & 8 & 16 & 32 & \\
\hline
\end{tabular}


Table 6 Distribution of medals among continents at the World Championships 2011 in Istanbul, 2015 in Las Vegas, 2017 in Paris, in Greco-Roman wrestling.

\begin{tabular}{|c|c|c|c|c|c|c|c|c|c|c|c|c|c|c|}
\hline \multirow{3}{*}{ № } & \multirow{3}{*}{ Continent } & \multicolumn{4}{|c|}{ World championship 2011 year } & \multicolumn{4}{|c|}{ World championship 2015 year } & \multicolumn{4}{|c|}{ World championship 2017 year } & \multirow{3}{*}{ Total } \\
\hline & & \multicolumn{3}{|c|}{ medals } & \multirow{2}{*}{-Total } & \multicolumn{3}{|c|}{ medals } & \multirow{2}{*}{ Total } & \multicolumn{3}{|c|}{ medals } & \multirow{2}{*}{-Total } & \\
\hline & & Gold & Silver & Bronze & & Gold & Silver & Bronze & & Gold & Silver & Bronze & & \\
\hline 1 & Europe & $5(71.4 \%)$ & $5(71.4 \%)$ & $9(64.3 \%)$ & $19(68 \%)$ & $7(87.5 \%)$ & $4(50 \%)$ & $110(62.5 \%)$ & $21(65.6 \%)$ & $66(75 \%)$ & $66(75 \%)$ & $10(62.5 \%)$ & $22(65.6 \%)$ & $62(67.4 \%)$ \\
\hline 2 & Asia & $2(28.6 \%)$ & $1(14.3 \%)$ & $4(28.5 \%)$ & $7(25 \%)$ & -- & $3(37.5 \%)$ & $55(31.25 \%)$ & $8(25 \%)$ & $22(25 \%)$ & $22(25 \%)$ & $44(50 \%)$ & $8(25 \%)$ & $23(25 \%)$ \\
\hline 3 & America & -- & $1(14.3 \%)$ & $1(7.2 \%)$ & $2(7 \%)$ & $1(12.5 \%)$ & $1(12.5 \%)$ & $11(6.25 \%)$ & $3(9.4 \%)$ & 00 & 00 & $22(25 \%)$ & $2(25 \%)$ & $7(7.6 \%)$ \\
\hline 4 & Africa & -- & -- & -- & -- & -- & -- & -- & - & -- & -- & -- & -- & -- \\
\hline 5 & Oceania & -- & -- & -- & $\begin{array}{l}- \\
-\end{array}$ & -- & -- & -- & - & -- & -- & -- & -- & -- \\
\hline \multicolumn{2}{|c|}{ Total medals } & 77 & 77 & 114 & 28 & 8 & 8 & 616 & 32 & 88 & 88 & 116 & 132 & 92 \\
\hline
\end{tabular}


The analysis of the World Championships and the Olympic Games reflects a significant superiority in the development of wrestling, especially the Greco-Roman wrestling in the countries of the European continent, which is $67.4 \%$ of the medals played. The second position is confidently occupied by the wrestlers of the Asian continent-25\%, the American continent-76\% remains in third place [8].

\section{Results and Conclusion}

Based on the results of the World Championships and Olympic Games inspected, the International Wrestling Federation (UWW United Wrestling World) should urgently take measures to promote and develop wrestling on all continents.

(1) Publish accessible, easily digestible, visual scientific and methodical literature, slides, films.

(2) Prepare and assign coaches, trainers, instructors, instructing them with programs for the development of wrestling based on the traditional features and capabilities of the continent, country, or region.

(3) Based on the postulate that the foundation and the basis of success in any human factor is "stability", it is necessary to develop and approve the rules and the program of competitions with a long-term perspective.

(4) To hold the draw of the competition participants in a festive, solemn, open, transparent atmosphere with the presentation of the titles of the participants of the competitions, with the invitation of representatives of the media, television.
(5) Find the opportunity to broadcast championships and world cups, tournaments of the Grand Prix series on TV chanel "Eurosport".

(6) Establish a prize fund for world championship winners: first place- $\$ 10,000$, second $-\$ 5,000$, third $-\$ 3,000$.

(7) Tournaments of the Grand Prix Series translate into the status of World Cup stages (for example, judo and other sports).

\section{References}

[1] Usenko, I. V. 2016. "Non-Olympic Results of the Sports Year." World of Sport 4 (65): 2-6.

[2] Korelin, A. A. 2005. Model of Highly Skilled Wrestler. Novosibirsk, 108-66.

[3] World Championship Wrestling 2017. https://ru/m/Wikipedia.org> wiki> Champ.

[4] Maksimovich, V. A. 2016. "Analytical Scientific and Methodological Approach to the Preparation of the National Team of the Republic of Belarus." World of Sport 3 (64): 14-9.

[5] Maksimovich, V. A. 2017. Wrestling, 3-130.

[6] Maksimovich, V. A., and Ivko, V. S. 2008. "Analysis of the XXIX Olympic Games and the Prospects for Preparing for the XXX Olympic Games in London in Greco-Roman Wrestling." World of Sport 4 (33): 8-17.

[7] Maksimovich, V. A., Ivko, V. S., and Gorodilin, S. K. 2012. "Comparative Characteristics of the Results of the Participation of the National Team of the Republic of Belarus in Greco-Roman Wrestling at the XXX Olympic Games 2012 in London and Innovative Approaches in Preparation for the XXXI Olympic Games 2016 in Rio de Janeiro." World of Sport 2 (47): 7-16.

[8] Platonov, V. N. 2004. "The System of Training Athletes in the Olympic Sport." In General Theory and Its Practical Applications. Kiev: Olympic literature. 